\title{
Mechanistic study of microstructural deformation and stress in steam-exploded softwood
}

\author{
Muhammad Muzamal ${ }^{1}$ - E. Kristofer Gamstedt ${ }^{2}$ • \\ Anders Rasmuson ${ }^{1}$
}

Received: 3 May 2016/Published online: 8 March 2017

(C) The Author(s) 2017. This article is published with open access at Springerlink.com

\begin{abstract}
Steam explosion pretreatment results in the formation of microcracks in the cell walls of wood. In the present study, steam explosion experiments were performed and structural changes in Norway spruce were identified using scanning electron microscopy. The cellular structure of the softwood spruce was simulated using the finite element method, and the effects of pressure generated during the steam explosion pretreatment on the deformation of the cells were investigated. The simulated model included earlywood, latewood, and ray cells. The effects of bordered and cross-field pits on the stresses in the cell wall were studied as well. Many similarities were observed between the microcracks in the steam-exploded wood and the high-stress regions predicted by the model. The experimental and simulation results showed that the radial cell walls in the earlywood cells experienced major deformation. The presence of the pits created stress localization and facilitated the formation of microcracks in the cell walls.
\end{abstract}

\section{Introduction}

Wood material is a widely available low-cost renewable resource from which many useful chemicals and biofuels can be derived (Goldstein 1981; Claassen et al. 1999). However, the complex cellular structure of wood makes it difficult for enzymes to penetrate and react with cellulose and hemicelluloses during the hydrolysis process (Grous et al. 1986). Steam explosion (SE) pretreatment creates pores and cracks in the cell walls which improve the accessibility of enzymes to polysaccharides (Wong

Anders Rasmuson

rasmuson@chalmers.se

1 Department of Chemistry and Chemical Engineering, Chalmers University of Technology, Gothenburg, Sweden

2 Department of Engineering Science, Uppsala University, Uppsala, Sweden 
et al. 1988; Donaldson et al. 1988). In SE pretreatment, the wood material is heated with saturated steam in a pressurized vessel which reduces the stiffness and strength of the wood. Then, the pressure in the vessel is suddenly reduced to atmospheric pressure. The pressure decrease inside the wood material is not as fast as the pressure decrease in the vessel. This causes a difference in the pressure between inside the wood and outside the wood in the vessel. Because of this pressure difference, the cells in the wood experience high stresses, which lead to damage and cracks in the cell walls. Additionally, the SE process has been implemented to enhance the drying of wood (Kanagawa et al. 1992; Zhang and Cai 2009). The explosive pressure release during the SE process increases the porosity of the material, which facilitates the drying of the wood.

The cells in softwood are arranged in longitudinal and radial directions. The longitudinal cells are mainly based on tracheids, and radial cells are based on mostly ray parenchyma, also called ray cells. The ultra-structure of a cell wall is constructed as a composite material in which cellulose microfibrils act as reinforcement and a mixture of hemicelluloses and lignin as the surrounding matrix. The tracheids wall is made of a primary layer $\mathrm{P}$ and secondary layers $\mathrm{S} 1, \mathrm{~S} 2$, and S3. Each layer differs in the composition of chemical constituents, microfibril angle (MFA), and thickness (Brändström 2001). The P layer has randomly oriented microfibrils, while the S1, S2, and S3 layers have unidirectional microfibrils. Cells in the wood are connected through a middle lamella (M) which is composed of hemicelluloses and lignin. Ray cells, on the other hand, have smaller cross-sectional size, thinner cell walls, shorter length and contain an extra secondary layer S4 (Harada and Wardrop 1960). Cells are connected through small pores called pits. The pits between tracheids are called bordered pits, and the pits between tracheids and ray cells are called cross-field pits. The number of bordered pits in softwood can be as high as 144 per tracheid (Meyer 1971). The presence of the bordered pit in a cell wall affects the MFA, and microfibrils in the pit border generally curve around the pit aperture (Imamura and Harada 1973). On the other hand, the local MFA of the small areas between the cross-field pits of earlywood tracheids usually shows uniform microfibril distribution (Sedighi-Gilani et al. 2005). The structure of a single wood cell is schematically presented in Fig. 1. Depending on the season of cell production, there are earlywood and latewood cells. These cells differ in terms of lumen size, cell wall thickness, and MFA.

Several researchers have modelled the cellular structure of wood using the finite element method. Qing and Mishnaevsky (2009) have simulated a bundle of a few cells with a hexagonal cross-sectional shape using 3-dimensional 8-node brick elements (C3D8). Persson (2000) has modelled a bundle of cells composed of earlywood and latewood cells by changing the cross-sectional size and thickness of the cells. Astley et al. (1998) have modelled the elastic properties of softwood using irregular cells with shell elements and found good agreement with experimental values. Sjölund et al. (2014) have studied the accuracy of the model with regular cell geometry, by comparing models with real and regular cell geometries. Those authors found that the error measure for geometric variation was small (between 5 and 13\%). Roope et al. (2012) have studied the effect of cross-field pits on the stress 


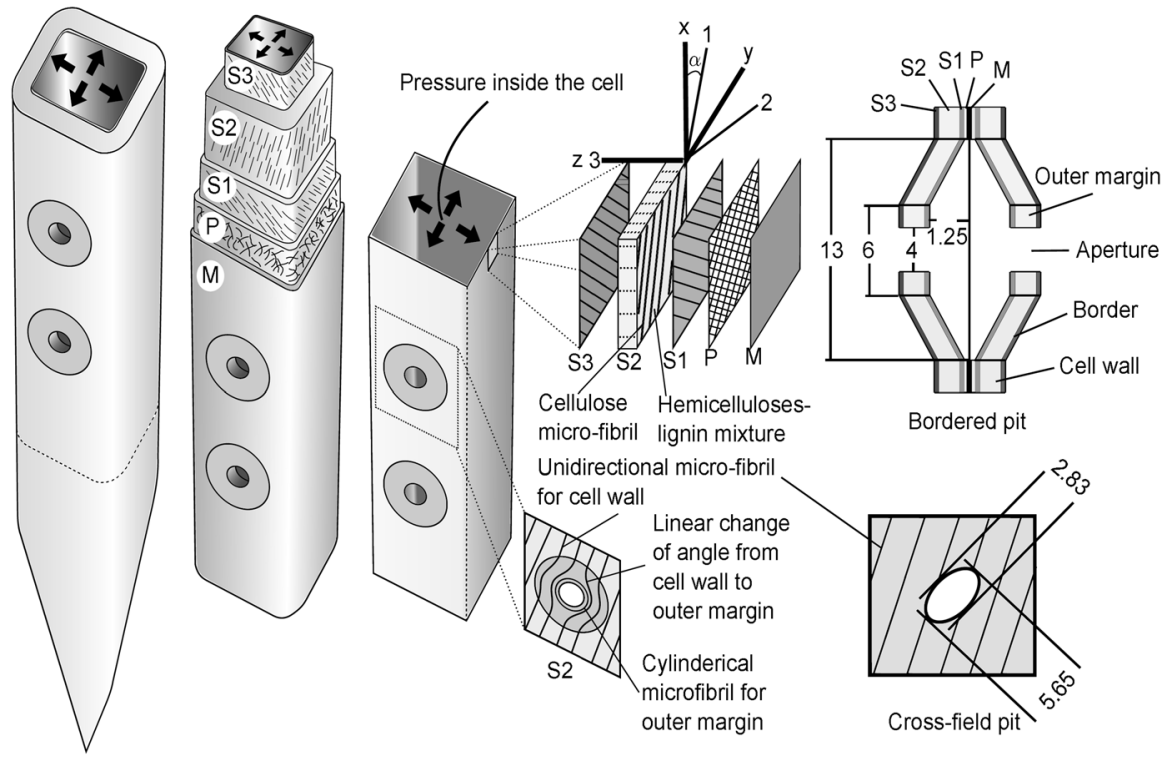

Fig. 1 Ultra-structure of a single cell showing wall layers, cross-field, and bordered pits

distribution in cell walls. It was found that the cross-field pits have a significant effect on the stress field in the cell wall.

The cellular structure of wood has been modelled to study the pulp and paper process as well. These processes take place at a high rate, and for this reason, the investigation of mechanics on the cellular scale by means of experiments is very impractical. The simulation of these processes using finite element method can provide useful information and play a role in process improvement. De Magistris and Salmén (2008) have modelled a bundle of cells with a square shape to study the wood cell deformation transverse to the fibre axis under compression and combined shear and compression load. These authors found out that the most important factor governing the deformation of fibres is the cell structure independently of material constants and number of cell wall layers used in the FEM models. The results showed that the cells collapse and undergo different deformation patterns as a result of compressive load. In a recent study by Fortino et al. (2015), a bundle of wood cells was modelled with square and hexagonal shapes to study cell wall stresses under transverse loading. The authors found out increasing values of cell angles cause decreasing stress levels at the same deformation. In both studies, good qualitative agreement between experiments and models was observed.

A number of experimental studies on SE pretreatment demonstrate the structural changes that take place in wood cells because of explosive pressure release (Tanahashi et al. 1982; Toussaint et al. 1991; Zhang and Cai 2006). Numerical modelling of the explosion steps can reveal the mechanisms and possible reasons behind such structural changes. This study has examined the effects of internal pressure created during SE pretreatment on a bundle of cells composed of earlywood and latewood cells. The importance of model size (number of cells in the 
model) has been investigated. In addition, the effect of internal pressure on ultrastructural features, i.e. ray cells and pits, has been modelled. However, the effect of variability of cell structure has been neglected in the present study. In this study, wood cells have been modelled as an orthotropic linear elastic material with a composite layup structure. The elastic properties of the softwood cells used for simulation were estimated at elevated conditions, 30\% moisture content (MC) at $160{ }^{\circ} \mathrm{C}$, in a previous study by the present authors (Muzamal et al. 2014). The simulation results have been qualitatively compared with experimentally obtained steam-exploded wood.

\section{Experimental procedures}

\section{Sample and steam explosion experiment}

In this study, experiments were performed in the SE equipment described in Muzamal et al. (2015) in order to make a qualitative comparison between experiments and modelling results. Wood samples of Norway spruce had dimensions of $20 \times 20 \times 4 \mathrm{~mm}^{3}$ (Longitudinal $\mathrm{L} \times$ Radial $\mathrm{R} \times$ Tangential $\mathrm{T}$ ). The surface of each sample was shaved and smoothed using a sharp blade prior to the SE experiments. During the SE experiments, wood chips were treated with saturated steam at 14 bar for $10 \mathrm{~min}$, which is a moderate operating condition (Wu et al. 1999). The conditions were limited by the maximum operating pressure of the SE equipment. The wood chips were contained inside a wire frame which prevented them from colliding with the walls of the equipment. After the steam treatment, the pressure in the vessel was rapidly reduced to atmospheric pressure using a pneumatically controlled gate valve.

\section{Scanning electron microscopy (SEM)}

SEM images of the outer surface of untreated and steam-exploded wood were taken using a Table-top ProX (Phenom, Netherlands) SEM equipped with a backscattered detector.

\section{Finite element model}

\section{Single cell}

In the present study, a simplified cellular structure of Norway spruce was modelled with a rectangular cross-sectional shape as this shape has less geometric parameters. The rectangular shape is defined according to some average of the cell structure geometry provided by the SEM image. However, it would be interesting to compare the model with hexagonal or irregular shape cells. The cell wall was modelled as a composite layup composed of five layers: a middle lamella M, a primary layer P, and the secondary layers S1, S2, S3. In the composite structure, the cellulose 
microfibrils comprised the fibres, and a mixture of hemicelluloses and lignin comprised the surrounding matrix. The chemical composition, thickness, and MFA of each cell wall layer of Norway spruce are given in Table 1.

\section{Model with earlywood and latewood cells}

The single cells were joined using the Tie constraint in ABAQUS. The Tie constraint restricts the joining surfaces from slip. During severe SE pretreatment, this constraint may not be fully valid since the connecting cells can slip and disconnect. However, due to the lack of information about contact properties, this method has been the preferred approach (De Magistris and Salmén 2008). The model composed of earlywood and latewood cells is shown in Fig. 2. The earlywood cells have a larger cross-sectional dimension and thinner cell walls than the latewood cells. Wood chips used for SE pretreatment have dimensions ranging from a few millimetres to a few centimetres, while the cross-sectional dimension of softwood cells ranges from 13 to $40 \mu \mathrm{m}$ (Fengel 1969). In other words, a wood chip is composed of several thousand cells. Modelling several thousand cells would be computationally very expensive. Therefore, a large enough model to represent the wood chips has to be simulated. The model shown in Fig. 2 has 11 columns of cells in the tangential direction, $\mathrm{T}$, and 24 rows of cells in the radial direction, $\mathrm{R}$. In the present study, the model was successively enlarged by increasing the number of cells in both the radial and the tangential directions. When enlarging the model in the tangential direction, a column of cells composed of 24 cells was added. The model was enlarged from the smallest model composed of $7 \times 24$ cells to $35 \times 24$ cells. The size of the largest model was restricted by the computational power of the computer. On the other hand, when the model was enlarged in the radial direction, a row of cells was added at the bottom of the model, and the model increased from $13 \times 24$ cells to $13 \times 30$ cells. The cells had a length of $30 \mu \mathrm{m}$ in the longitudinal direction which was sufficient to incorporate the longitudinal effects of model geometry. Successive simulations (convergence tests) were performed to ensure that the mesh was sufficiently dense. The elements used were linear quadrilateral continuum shell elements with reduced integration and hourglass control. In order to avoid convergence problems, Nlgeom (nonlinear geometry) was turned on.

Table 1 Component percentage, thickness, and MFA of different layers of a softwood cell (Bodig and Jayne 1982; Brändström 2001)

\begin{tabular}{llllll}
\hline & Cellulose & Hemicellulose & Lignin & Thickness $(\mu \mathrm{m})$ & MFA \\
\hline S3 & 46 & 36 & 18 & 0.09 & $-40^{\circ}$ \\
S2 & 48 & 30 & 21 & Variable & $10^{\circ}$ \\
S1 & 26 & 30 & 44 & 0.26 & $-50^{\circ}$ \\
P & 14 & 30 & 55 & 0.09 & Random \\
M & 0 & 40 & 59 & 0.45 & $0^{\circ}$ \\
\hline
\end{tabular}




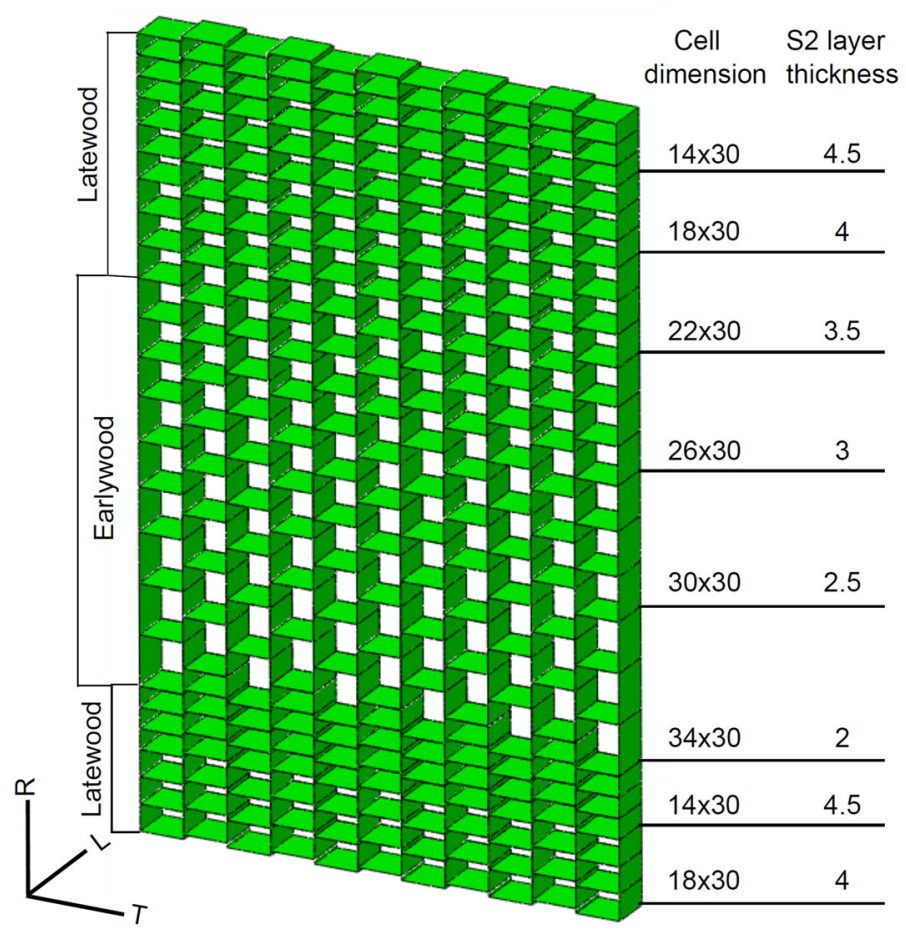

Fig. 2 Structure, dimensions, and direction of cells in the model (all values are in $\mu \mathrm{m}$ ). Model with $11 \times 24$ cells

\section{Model with pits and ray cells}

In order to simulate the effect of internal pressure on pits and ray cells, a separate model was developed. As shown in Fig. 3, the model had twenty longitudinal tracheids and five radial ray cells. Each tracheid wall had two bordered pits. The structure and dimensions of the bordered pit are shown in Fig. 1 (Schulte 2012). The bordered pit was made of a bordered part, an outer-margin, and an opening called the aperture. According to Imamura and Harada (1973), the microfibril angle changes from unidirectional in the cell wall to circular in the outer-margin of the bordered pit. In the present study, the microfibrils in the outer-margin curved around the pit aperture and were unidirectional in the cell wall. The MFA values in pit border were calculated using linear interpolation from cell wall to outer-margin (see Fig. 3b). The bordered part of the pit was made of S1, S2, and S3 layers as the $M$ and P layers are not present in the bordered part (Murmanis and Sachs 1969). The cross-field pits between tracheids and ray cells were modelled as elliptic holes at a $45^{\circ}$ angle in the cell walls. The dimensions of the cross-field pits were taken from SEM images of Norway spruce. The microfibrils in the cell wall around the crossfield pits were unidirectional (Sedighi-Gilani et al. 2005). The cross-sectional dimension of the square tracheid was $30 \mu \mathrm{m}$, and the S2 layer thickness was $2 \mu \mathrm{m}$. In contrast, the cross-sectional dimension of the rectangular ray cell was 


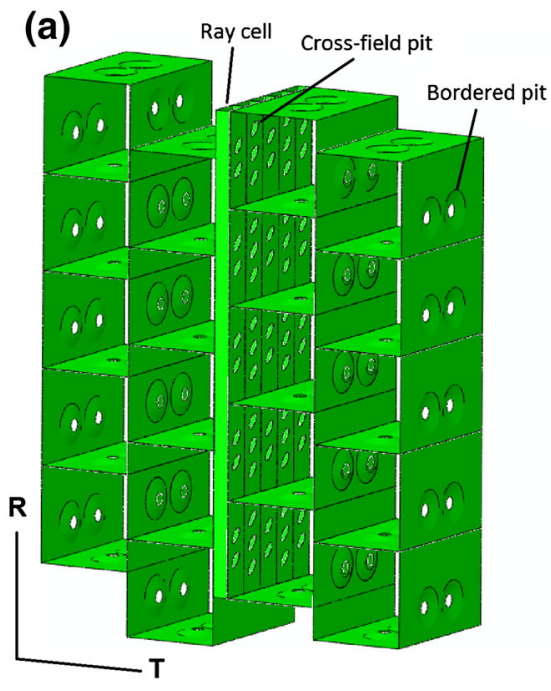

(b)

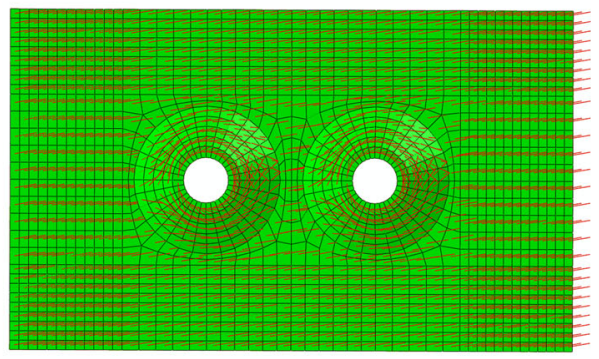

Fig. 3 a Model with bordered pits, cross-field pits, and ray cells, b mesh and MFA of S2 layer around bordered pit

$5 \times 10 \mu \mathrm{m}^{2}$, and the $\mathrm{S} 2$ layer thickness was $1 \mu \mathrm{m}$. In order to resolve such complex geometrical features, the mesh in the model used was very fine. This made the model computationally heavy and limited the total number of cells to 20 tracheids and 5 ray cells.

The wood cells were modelled as an orthotropic linear elastic material. The damage in the material was not modelled because the strength properties of the cell wall were not available at the operating conditions of SE pretreatment. In order to simulate the effects of the high-pressure difference between the inside and outside of the wood cells during the SE pretreatment, a uniform pressure of 8.013 was applied inside each cell, and atmospheric pressure (1.013 bar) was applied to the outside of the outermost cell walls. The net pressure inside the cells was thus 7 bar. Although steam explosion experiments were performed at 14 bar, the modelling was performed only at a 7-bar pressure difference. This was because data on the elastic properties were only available up to these conditions. However, for the analysed structures with uniform cells the patterns of stress concentration would appear the same irrespective of the pressure level. In this study, only the initial phase of the SE pretreatment was analysed and it was assumed that the pressure was the same in the whole chip. The stress and strain of a two-dimensional linear elastic orthotropic material are related as

$$
\left\{\begin{array}{l}
\varepsilon_{11} \\
\varepsilon_{22} \\
\gamma_{12}
\end{array}\right\}=\left[\begin{array}{ccc}
1 / E_{11} & -v_{21} / E_{22} & 0 \\
-v_{12} / E_{11} & 1 / E_{22} & 0 \\
0 & 0 & 1 / G_{12}
\end{array}\right]\left\{\begin{array}{l}
\sigma_{11} \\
\sigma_{22} \\
\sigma_{12}
\end{array}\right\}
$$




\section{Mechanical properties of the cell wall}

The mechanical properties of the cell wall layers of Norway spruce were estimated in a previous study by the present authors (Muzamal et al. 2014) at elevated conditions ( $160{ }^{\circ} \mathrm{C}$ and $30 \% \mathrm{MC}$ ). The properties were estimated using the elastic properties of cellulose, hemicelluloses, and lignin at ambient conditions $\left(20{ }^{\circ} \mathrm{C}\right.$ and $12 \% \mathrm{MC})$. The elastic properties $E_{22}$ and $G_{12}$ of unidirectional layers, i.e., secondary wall and middle lamella, were calculated using the Halpin-Tsai (Halpin and Kardos 1976) equations. A simple rule of mixing, i.e., volume fraction average, was used to calculate $E_{11}$ and $v_{12}$. For the primary layer with long random microfibrils, the properties were calculated using classical laminate theory, see, for example Tsai (1992). In order to calculate elastic properties at elevated conditions, the elastic properties at ambient conditions were multiplied by certain factors. These factors were based on the experiments of Keunecke et al. (2007) and Salmén and Fellers (1982). For detailed information regarding the estimation of these properties, see Muzamal et al. (2014). The final elastic properties of each cell wall layer at $160{ }^{\circ} \mathrm{C}$ and $30 \% \mathrm{MC}$ are given in Table 2. Owing to the lack of direct measurements, it should be noted that these are extrapolated values using a model based on measurements at lower temperatures.

\section{Results and discussion}

\section{Experimental}

Figure 4 shows the SEM images of the outermost radial cell wall of untreated and steam-exploded wood. The surface in the figure appears smooth as it was shaved with a razor blade prior to the experiments. The shaving was necessary, as the samples were prepared by saw cutting which made the outer surface very rough and the comparison between untreated and steam-exploded samples difficult (Muzamal et al. 2015). Several microcracks are visible on the outermost radial cell walls of the steam-exploded wood in Fig. 4b. The microcracks appeared in the cell wall at some angle to the longitudinal axis of the tracheids. Small cracks seemed to join and form larger cracks oriented in the longitudinal direction. These cracks were not observed in the cell walls deep inside the sample. It seems that the explosive release of

Table 2 Estimated elastic properties of different layers of the cell at $160{ }^{\circ} \mathrm{C}$ and $30 \% \mathrm{MC}$ in local coordinates (Muzamal et al. 2014)

\begin{tabular}{lllllr}
\hline & $\mathrm{M}$ & $\mathrm{P}$ & $\mathrm{S} 1$ & $\mathrm{~S} 2$ & $\mathrm{~S} 3$ \\
\hline$E_{11}(\mathrm{GPa})$ & 1.4 & 3.3 & 1.1 & 9.5 & 2.0 \\
$E_{22}(\mathrm{GPa})$ & 0.2 & 1.1 & 1.1 & 0.6 & 1.1 \\
$G_{12}(\mathrm{GPa})$ & 0.3 & 0.9 & 0.3 & 0.6 & 0.4 \\
$v_{12}$ & 0.26 & 0.38 & -0.21 & 0.096 & -0.39 \\
\hline
\end{tabular}



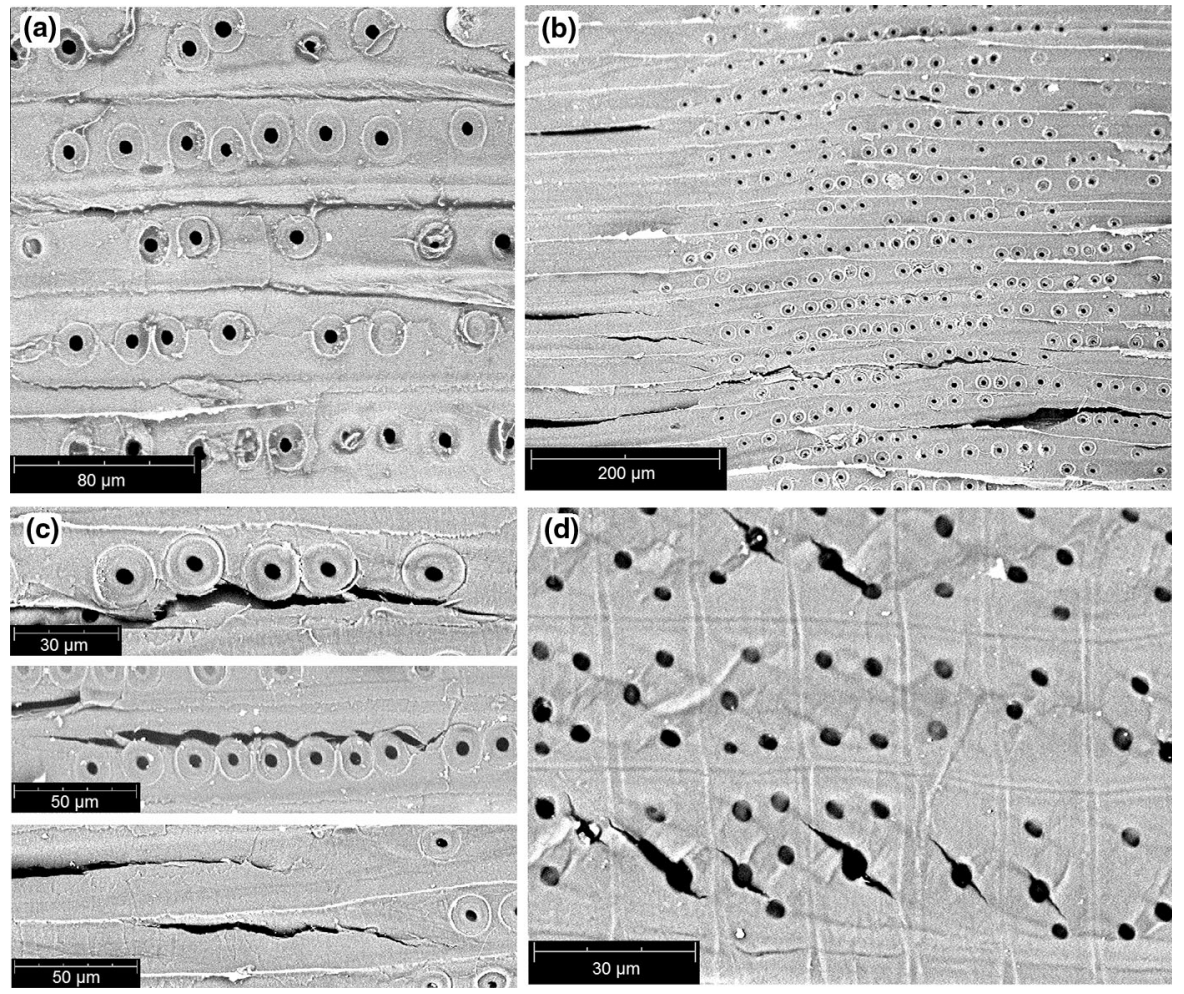

Fig. 4 SEM images of a untreated, b steam-exploded wood, $\mathbf{c}$ enlarged microcracks in cell walls of steam-exploded wood, $\mathbf{d}$ microcracks near cross-field pits of steam-exploded wood
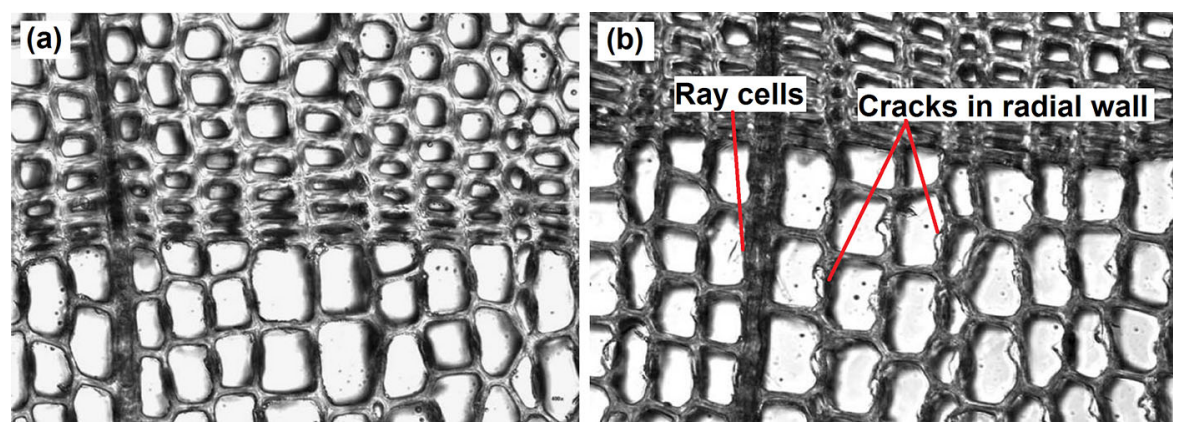

Fig. 5 SEM images of a untreated, b steam-exploded sub-alpine fir at $160{ }^{\circ} \mathrm{C}$ for $1 \mathrm{~h}$ (Zhang and Cai 2006)

pressure, under moderate operating conditions, was not severe enough to create cracks on the inner cell walls. The SE pretreatment at severe conditions might result in more microcracks in the cell walls. On the other hand, microcracks have been observed in the inner cell walls of steam-exploded wood by Zhang and Cai (2006), probably due to more severe pretreatment conditions (Fig. 5). Closer observation of 
the microcracks in Fig. 4c shows that the cracks curve around the bordered pits and do not pass through them. In contrast, Fig. 4d shows that the microcracks near cross-field pits mostly originate from the poles of elliptic holes. Similar microcracks were observed by Zhang and Cai (2006) near cross-field pits. The SEM image of the steam-exploded softwood presented by Zhang and Cai (2006) in Fig. 5 shows that the earlywood cells have been damaged more than the latewood cells. An interesting feature of the microcracks is that they mostly appear on the radial cell walls, while tangential cell walls seem free from damage. In addition, the cell walls attached to ray cells in the figure appear less damaged than the other radial cell walls.

\section{Finite element model}

In SE pretreatment, wood chips are treated with saturated steam at a high temperature which reduces their stiffness. The steam treatment step was incorporated into the simulation by estimating the reduced elastic properties of wood cells at elevated conditions, i.e., $30 \% \mathrm{MC}$ and $160{ }^{\circ} \mathrm{C}$.

\section{Model consisting of earlywood and latewood cells}

The deformed model (with deformation scale factor $=1$ ) presented in Fig. 6 comprises $35 \times 24$ cells and has a dimension of $1050 \times 528 \mu^{2}$. It can be seen in the figure that the cells have expanded and large stresses are visible in some parts of the cells as a result of internal pressure. The regions with high stresses in the weak direction, i.e., perpendicular to the microfibrils, are more prone to break during SE pretreatment. Stress states in different parts of the cell have been briefly discussed by the present authors in a previous study (Muzamal et al. 2014). Figure 6 shows that the earlywood cells have deformed more than the latewood cells. This is quite obvious, since they have a larger cross-sectional size and thinner cell walls. It
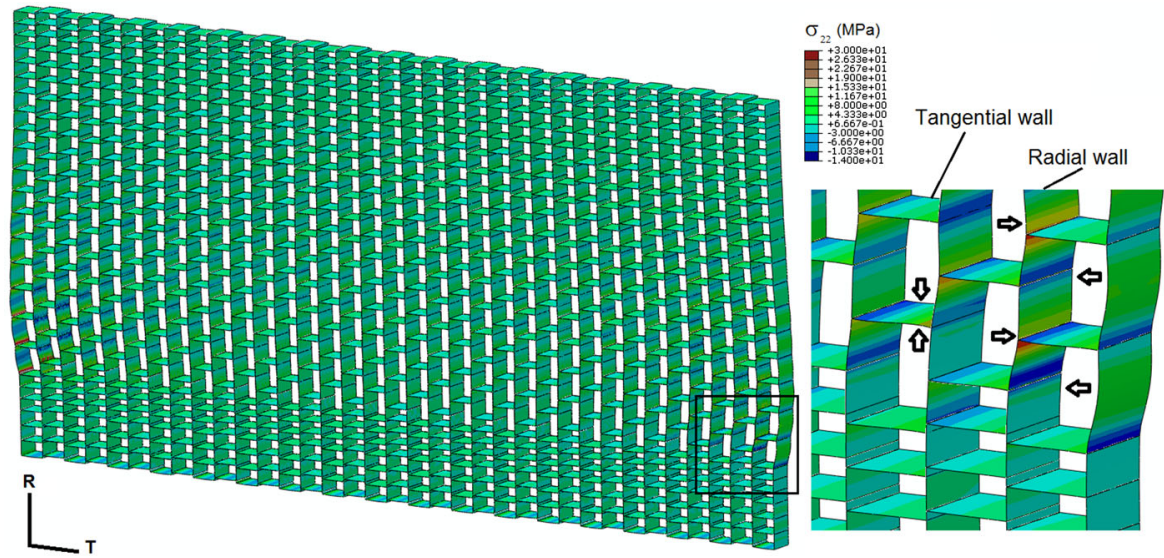

Fig. 6 Simulation results: stress perpendicular to microfibrils, $\sigma_{22}(\mathrm{MPa})$, on the inside and outside of the cells shown on deformed model composed of $35 \times 24$ cells 
should be noted that the radial cell walls have experienced greater deformation than the tangential cell walls. A plausible reason for the major deformation in the radial cell walls can be the geometric arrangement of the cells, which creates uneven stresses on the radial cell walls, whereas stresses on the tangential cell walls are balanced as shown by the arrows in Fig. 6. Zhang and Cai (2006) have also observed microcracks in the radial cell walls of the earlywood cells (see Fig. 5).

Figure 7a shows the effect of increasing the model size (number of cells) in the tangential direction on the maximum stress perpendicular to the microfibrils, $\sigma_{22}$, in the S2 layer of earlywood cells. These cells are highlighted in Fig. 7b. The model size was increased from $7 \times 24$ cells to $35 \times 24$ cells by successively adding a column consisting of 24 cells on the right-hand side of the model. It can be seen that the maximum stress in the outermost cell increases with an increase in model size. In contrast, the maximum stress decreases in the centre cell. However, the change in
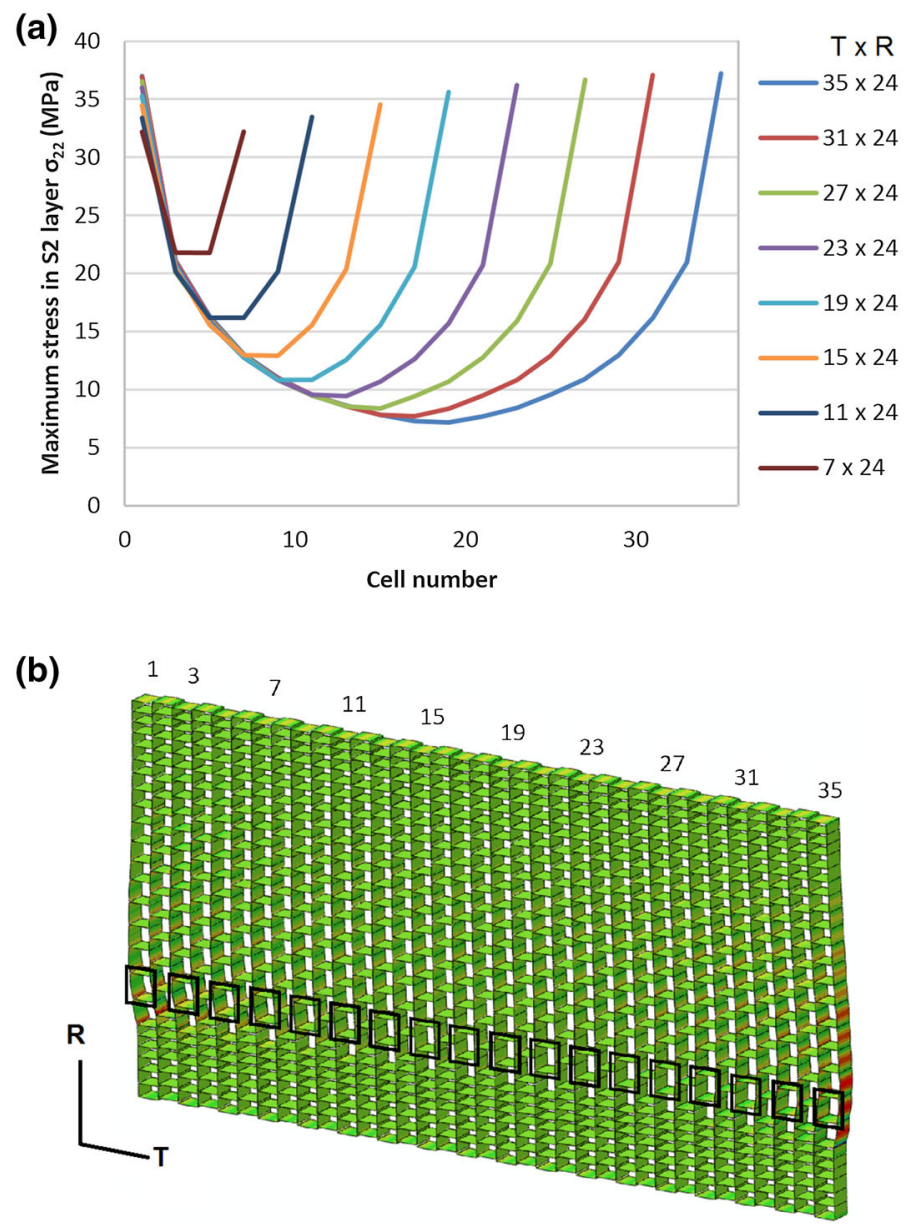

Fig. 7 a Effect of increasing the number of cells in the tangential direction on the maximum stress perpendicular to the microfibrils in the S2 layer of the cells highlighted in the small model in (b) 
stress decreases with an increase in model size. For instance, the change in stress in the outermost cell was $3.9 \%$ when the model size was increased with additional layers of 4 cells from $7 \times 24$ cells to $11 \times 24$ cells, and it became $0.32 \%$ when increased from $31 \times 24$ to $35 \times 24$ cells. It is expected that for a sufficiently large model, the stresses in the centre and the outermost cell would essentially become independent of model size. The initial trend of this reduced chip size dependency can be observed in Fig. 7a. The plot in Fig. 7a shows that the stress is high in the first cell and then decreases. This is because atmospheric pressure was applied to the outside of the first cell and high pressure prevailed on the inside of the cell. Furthermore, it can be observed that major stress and deformation exist in only a few cells close to the edge while most interior cells have minor stresses. A reason for this type of deformation in the tangential direction can be the presence of stronger latewood cells, which affect the deformation in the earlywood cells. In order to obtain significantly higher average stress in a wood chip, it would need to be very small in the tangential direction, 30 cells or so, which is too small for chipping and requires too much energy.

In another set of simulations, the model was increased in the radial direction from $13 \times 24$ cells to $13 \times 30$ cells by adding three rows of 13 cells at the bottom of the model. Similar to the first cell in the transverse direction, the plot in Fig. 8a shows that the stress is high in the first cell. The plot in the figure confirms that the deformation is the least in latewood cells and the greatest in earlywood cells. Moreover, increasing the cells in the radial direction had less effect on the other cells as the strong latewood cells did not affect the other cells in this direction. Therefore, it is better to have chips used for SE pretreatment extended radially rather than tangentially.

(a)

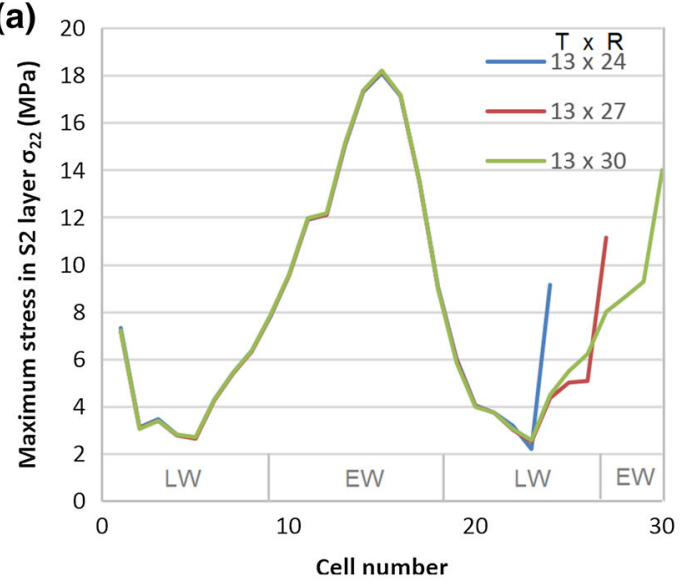

(b)

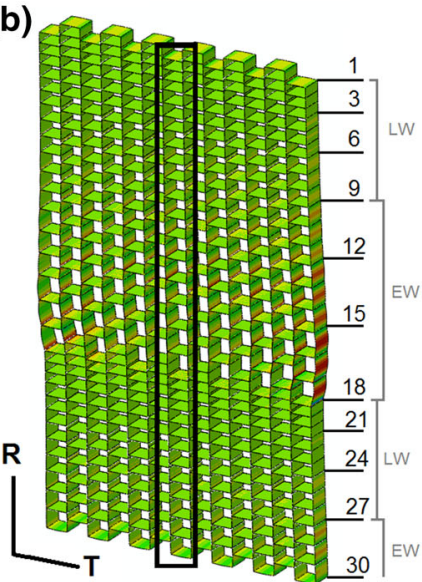

Fig. 8 a Effect of increasing the number of cells in the radial direction on the maximum stress perpendicular to the microfibrils in the S2 layer of the cells highlighted in the small model in (b), also showing earlywood $(\mathrm{EW})$ and latewood $(\mathrm{LW})$ regions 


\section{Model containing pits and ray cells}

The deformed model (deformation scale factor $=1$ ) with pits and ray cells shown in Fig. 9 reveals that the stresses are the highest in the cell corners. However, on the outside of the cell, high-stress regions curve around the bordered pits (Fig. 10a, b). It seems that the circumventing microfibrils in the outer-margin and the structure of the bordered pit reinforce this region. The shape of the high-stress region correlates with the cracks formed in the steam-exploded wood (Fig. 4c). Closer observation of the cell walls in Fig. 10a, b shows that the location of the pits in the cell walls affects the stress. The presence of cross-field pits on the cell walls also creates stress localization and facilitates the formation of cracks (Fig. 10c). High stresses are visible at the poles of the elliptic pit, which is the same location where microcracks were observed in the steam-exploded wood (Fig. 4d). Figure 9 shows that the ray cells experience much weaker stresses than the tracheids. A smaller cross-sectional size of ray cells and the connection with tracheids in the perpendicular direction create a stronger structure. The tracheid walls next to ray cells experience less deformation, which is also visible in the SEM micrograph of the steam-exploded wood (Fig. 5b).

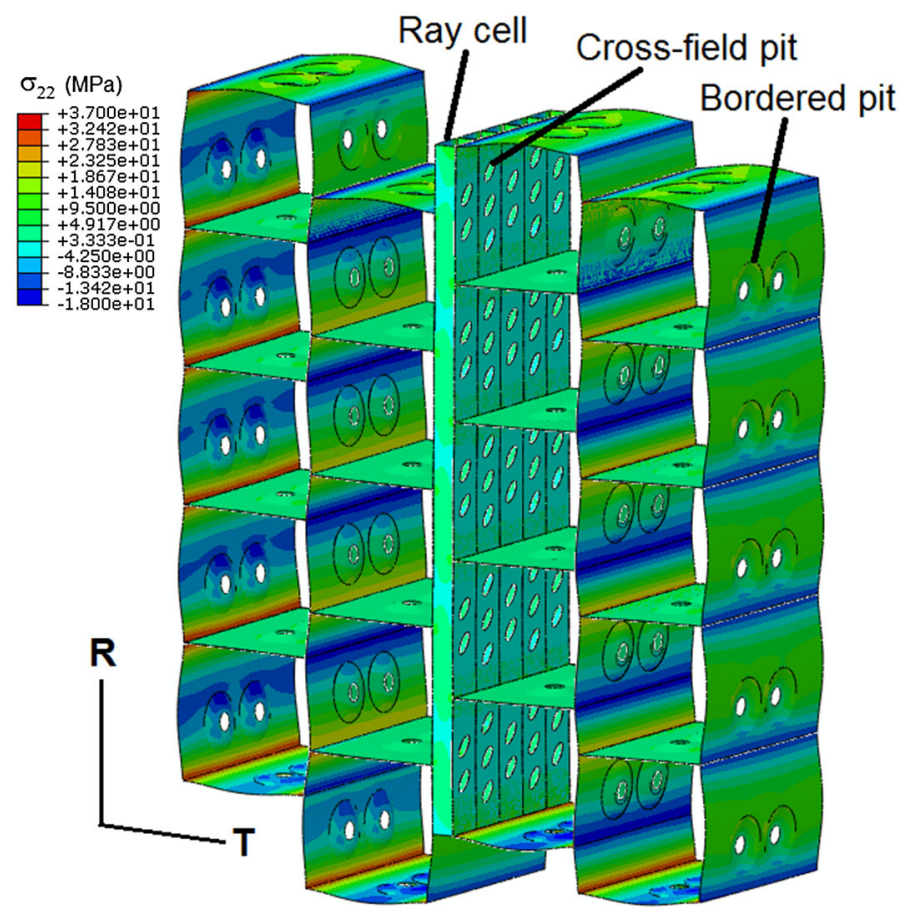

Fig. 9 Stress perpendicular to microfibrils, $\sigma_{22}(\mathrm{MPa})$, on the inside and outside of the S2 layer shown on deformed model containing ray cells and tracheids with bordered pits and cross-field pits 


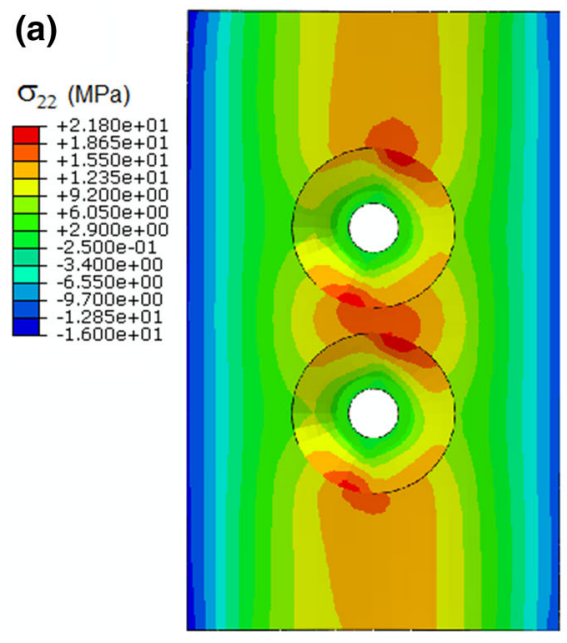

(b)

$\sigma_{22}(\mathrm{MPa})$
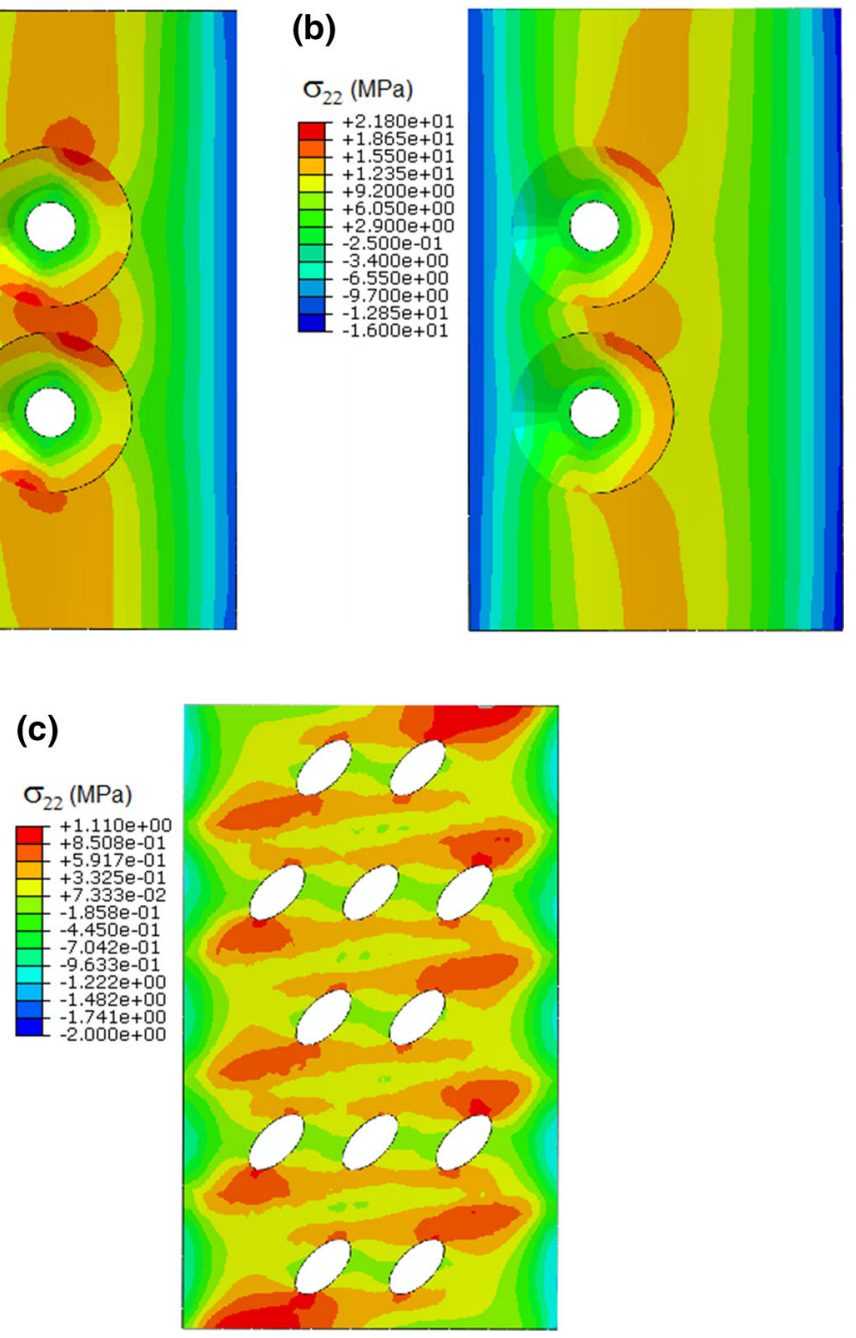

Fig. 10 Stress perpendicular to microfibrils in the S2 layer around bordered pits in (a) and (b), and around cross-field pits in (c)

\section{Conclusion}

The pressure build up inside wood cells during steam explosion pretreatment has been shown to create microcracks in the cell walls. Modelling the process revealed the areas in the cellular structure of wood which are prone to break as a result of the internal pressure caused by the steam explosion. High-stress regions predicted by the model correlated well with the microcracks observed in steam-exploded wood. It was found that earlywood cells deform more than latewood cells since they have larger cross-sectional dimensions and thinner cell walls. Increasing the model size in the tangential direction revealed that the latewood cells restricted the deformation 
of cells in this direction. Increasing the model size in the radial direction, on the other hand, did not affect the deformation of other cells. In other words, wood chips used for steam explosion should have larger dimensions in the radial direction than in the tangential direction. The circumventing microfibrils in the inner margin of bordered pits reinforced this region, and the microcracks formed during steam explosion curved around the pits and did not pass through the pits. The presence of cross-field pits localized the stresses at the poles of the pits and induced cell wall cracking.

To improve the present model, the stress-state analysis can be complemented with damage (e.g. Hashin 1980) or a failure criterion (Flores and Friswell 2013; Neagu et al. 2006). A criterion can be included to identify the internal pressure which would create microcracks in the cell walls. The stress component transverse to the microfibrils in the S2 layer, $\sigma_{22}$, is considered to be the most important component in cracking a cell wall, but general in-plane stress-based criteria can account for the effect of the other stress components, notably the in-plane shear stress, $\tau_{12}$. In addition, a model with variability of cell structure could be tested to understand the influence of possible different stress levels in the cell walls.

Acknowledgements The authors would like to thank Chalmers Energy Initiative for financial support.

Open Access This article is distributed under the terms of the Creative Commons Attribution 4.0 International License (http://creativecommons.org/licenses/by/4.0/), which permits unrestricted use, distribution, and reproduction in any medium, provided you give appropriate credit to the original author(s) and the source, provide a link to the Creative Commons license, and indicate if changes were made.

\section{References}

Astley RJ, Stol KA, Harrington JJ (1998) Modelling the elastic properties of softwood. Part II: the cellular microstructure. Holz Roh Werkst 56:43-50

Bodig J, Jayne BA (1982) Mechanics of wood and wood composites. Van Nostrand Reinhold, New York

Brändström J (2001) Micro- and ultrastructural aspects of Norway spruce tracheids: a review. IAWA J 22(4):333-353

Claassen PAM, van Lier JB, Contreras AML, van Niel EWJ, Sijtsma L, Stams AJM, de Vries SS, Weusthuis RA (1999) Utilisation of biomass for the supply of energy carriers. Appl Microbiol Biotechnol 52:741-755

De Magistris F, Salmén L (2008) Finite Element modelling of wood cell deformation transverse to the fibre axis. Nord Pulp Paper Res J 23(2):240-246

Donaldson LA, Wong KKY, Mackie KL (1988) Ultrastructure of steam-exploded wood. Wood Sci Technol 22:103-114

Fengel D (1969) The ultrastructure of cellulose from wood. Part 1: wood as the basic material for the isolation of cellulose. Wood Sci Technol 3:203-217

Flores EIS, Friswell MI (2013) Ultrastructural mechanisms of deformation and failure in wood under tension. Int J Solids Struct 50(13):2050-2060

Fortino S, Hradil P, Salminen LI, De Magistris F (2015) A 3D micromechanical study of deformation curves and cell wall stresses in wood under transverse loading. J Mater Sci 50:482-492

Goldstein IS (1981) Organic chemicals from biomass. CRC Press, Boca Raton

Grous WR, Converse AO, Grethlein HE (1986) Effect of steam explosion pretreatment on pore size and enzymatic hydrolysis of poplar. Enzyme Microb Technol 8:274-280 
Halpin JC, Kardos JL (1976) The Halpin-Tsai equations: a review. Polym Eng Sci 16(5):344-352

Harada H, Wardrop AB (1960) Cell wall structure of ray parenchyma cells of a softwood. J Jpn Wood Res Soc 6(1):34-41

Hashin Z (1980) Failure criteria for unidirectional fiber composites. J Appl Mech 47:329-334

Imamura Y, Harada H (1973) Electron microscopic study on the development of the bordered pit in coniferous traeheids. Wood Sci Technol 7:189-205

Kanagawa Y, Hayashi K, Yasuzima M (1992) Improvement of dryability by local steam explosion for Japanese cedar. In: 3rd IUFRO wood drying conference

Keunecke D, Sonderegger W, Pereteanu K, Luthi T, Niemz P (2007) Determination of Young's and shear moduli of common yew and Norway spruce by means of ultrasonic waves. Wood Sci Technol 41:309-327

Meyer RW (1971) Influence of pit aspiration on earlywood permeability on douglas-fir. Wood Fiber Sci 4:328-339

Murmanis L, Sachs IB (1969) Structure of pit border in Pinus strobus L. Wood Fiber Sci 1:7-17

Muzamal M, Gamstedt EK, Rasmuson A (2014) Modeling wood fiber deformation caused by vapor expansion during steam explosion of wood. Wood Sci Technol 48:353-372

Muzamal M, Jedvert K, Theliander H, Rasmuson A (2015) Structural changes in spruce wood during different steps of steam explosion pretreatment. Holzforschung 69(1):61-66

Neagu RC, Gamstedt EK, Bardage SL, Lindström M (2006) Ultrastructural features affecting mechanical properties of wood fibres. Wood Mater Sci Eng 1:146-170

Persson K (2000) Micromechanical modelling of wood and fiber properties. PhD Thesis, Department of Mechanics and Materials, Lund University, Lund

Qing H, Mishnaevsky L Jr (2009) 3D hierarchical computational model of wood as a cellular material with fibril reinforced, heterogeneous multiple layers. Mech Mater 41:1034-1049

Roope E, Hämäläinen J, Leppänen T (2012) Finite element modeling of the effect of crossfield pits on the cell wall stress behavior. Nord Pulp Paper Res J 27(3):647-652

Salmén L, Fellers C (1982) The fundamentals of energy consumption during viscoelastic and plastic deformation of wood. Pulp Paper Can Trans Tech 4(9):93-99

Schulte PJ (2012) Computational fluid dynamics models of conifer bordered pits show how pit structure affects flow. New Phytol 193:721-729

Sedighi-Gilani M, Sunderland H, Navi P (2005) Microfibril angle non-uniformities within normal and compression wood tracheids. Wood Sci Technol 39:419-430

Sjölund J, Karakoc A, Freund J (2014) Accuracy of regular wood cell structure model. Mech Mater 76:35-44

Tanahashi M, Takada S, Aoki T, Goto T, Higuchi T, Hanai S (1982) Characterization of Explosion Wood 1. Structure and physical properties. Wood Res 69:36-51

Toussaint B, Excoffier G, Vignon MR (1991) Effect of steam explosion treatment on the physicochemical characteristics and enzymic hydrolysis of poplar cell wall components. Anim Feed Sci Technol 32:235-242

Tsai SW (1992) Theory of composites design. Think Composites, Dayton

Wong KKY, Deverell KF, Mackie KL, Clark TA, Donaldson LA (1988) The relationship between fiber porosity and cellulose digestibility in steam-exploded Pinus radiata. Biotechnol Bioeng 31:447-456

Wu MM, Chang K, Gregg DJ, Boussaid A, Beatson RP, Saddler JN (1999) Optimization of steam explosion to enhance hemicellulose recovery and enzymatic hydrolysis of cellulose in softwoods. Appl Biochem Biotechnol 77-79:47-54

Zhang Y, Cai L (2006) Effect of steam explosion on wood appearance and structure of sub-alpine fir. Wood Sci Technol 40:427-436

Zhang Y, Cai L (2009) Mechanism for de-aspirating pits in subalpine fir by steam explosion prior to drying. Dry Technol 27:84-88 